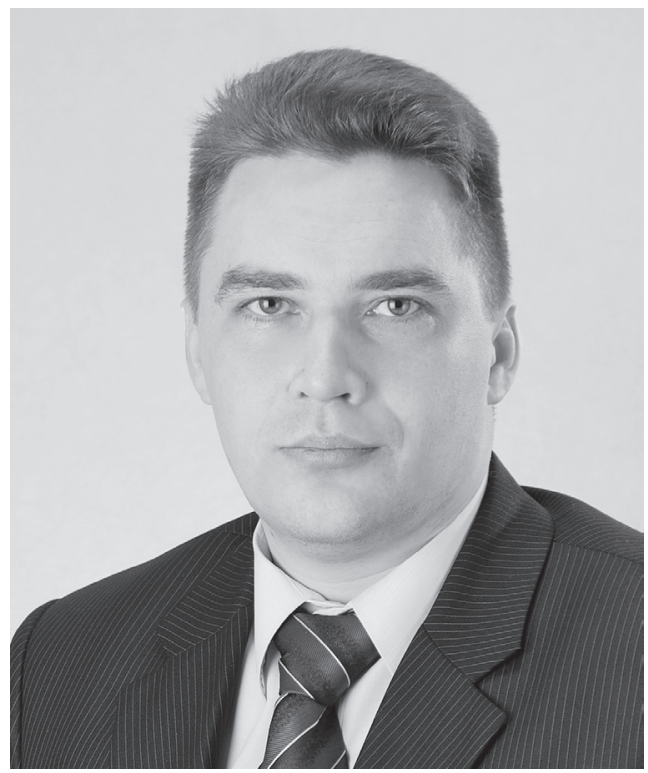

Прилипко Сергей Михайлович, кандидат экономических наук, дочент, докторант кафедры публичного управления $и$ публичной службы, Национальная академия государственного управления при Президента Украины, 03057, г. Киев, ул. Антона Цедика, 20, тел.: (067) 70836 79, е-таіl: agroadvice@ukr.net
UDC: $351: 631.115 .8$

DOI: https://doi.org/10.32689/2617-

2224-2019-17-2-238-249

Prylipko Sergii Mykhailooych,

PhD in Economics, Associate Professor, Doctoral Candidate of the Department of Public Administration and Public Service, National Academy for Public Administration under the President of Ukraine, 03057, Kyiv, Str. Antona Tsedika 20, tel.: (067) 70836 79, e-mail: agroadvice@ukr.net

ORCID: 0000-0002-6116-328X

\section{Приліпко Сергій Михайлович,}

кандидат економічних наук, доцент, докторант кафедри публічного управління та публічної служби, Наміональна академія державного управління при Президентові України, 03057, м. Киів, вул. Антона Цедіка, 20, тел.: (067) 70836 79, е-таil: agroadvice@ukr.net

ORCID: 0000-0002-6116-328X

\title{
HISTORY OF BECOMING AND DEVELOPMENT OF COOPERATIVE MOVEMENT IN UKRAINE AT THE END OF XIX - AT THE BEGINNING OF XX CENTURIES
}

Abstract. The article states that the cooperative movement has become widespread in order to overcome the socio-economic problems of rural communities and restructuring of the social system at the end of XIX - at the beginning of the XX centuries in various regions of Ukraine, which subsequently became the national socio-economic phenomenon. The formation of service cooperatives was carried out through the creation of agricultural partnerships and their associations in cooperative unions, federations and development centers. It was proved that the formation of a cooperative movement did not take place without the intervention of public authorities, which in addition to the adoption of relevant normative documents constantly tried to impose their party ideology to the 
citizens through collaboration with cooperative system. It was established that at the same time the cooperative institutions influenced on the political life of the country through the financing of parties and fulfilling the propaganda work among the population.

It was determined that the spread of cooperation was due to the mass involving of cooperatives and their institutions to the cultural-educational, information-educational and upbringing work. In particular, the special attention was paid to the creation of cooperative circles, schools, libraries, carrying out of demonstrative shows and exhibitions, organization of hire stations of agricultural machinery and equipment.

The expediency of taking into account the historical experience of the formation and development of cooperation as a social and economic phenomenon in the state in the current conditions of the reform of decentralization of power and the emergence of rural united territorial communities was summarized. It was noted that it is necessary to focus the attention on the main ideological and organizational principles of the revival and development of the Ukrainian cooperative movement, education of nationally conscious members of society, raising the cultural-educational and financial-economic level of the population for the successful development of rural areas of Ukraine.

Keywords: agrarian policy, cooperation, cooperative movement, cooperative association, informational-educational activity.

\section{ІСТОРІЯ СТАНОВЛЕННЯ ТА РОЗВИТКУ КООПЕРАТИВНОГО РУХУ В УКРАЇНI В КІНЦІ ХІХ - НА ПОЧАТКУ ХХ СТ.}

Анотація. Зазначено, що 3 метою подолання соціально-економічних проблем сільських громад і перебудови суспільного ладу наприкінці XIX - на початку XX ст. у різних регіонах України поширення набув кооперативний рух, який згодом став загальнодержавним соціально-економічним явищем. Формування обслуговуючої кооперації здійснювалось через створення сільськогосподарських товариств та їх об’єднань у кооперативні спілки, союзи та центри розвитку. Доведено, що становлення кооперативного руху не відбувалося без втручання органів державної влади, які крім прийняття відповідних нормативних документів постійно намагалися нав’язати громадам партійну ідеологію через співпрацю з кооперативною системою. Встановлено, що кооперативні установи впливали на політичне життя країни через фінансування партій та проведення агітаційної роботи серед населення.

3'ясовано, що поширення кооперації відбувалося через масове здійснення кооперативами та ї інституціями культурно-просвітницької, інформаційно-консультативної та освітньої роботи. Зокрема, особлива увага приділялася створенню кооперативних гуртків, шкіл, бібліотек, проведенню демонстраційних показів і виставок, організації прокатних станцій сільськогосподарської техніки й обладнання.

Резюмовано доцільність врахування історичного досвіду становлення і розвитку кооперації як соціально-економічного явища у державі за сучас- 
них умов проведення реформи децентралізації повноважень влади та появи сільських об'єднаних територіальних громад. Зазначено, що для успішного розвитку сільських територій України слід зосередити увагу на основних ідеологічно-організаційних засадах відродження і розвитку українського кооперативного руху, вихованні національно свідомих членів суспільства, підвищенні культурно-освітнього та фінансово-економічного рівня населення.

Ключові слова: аграрна політика, кооперація, кооперативний рух, кооперативне об’єднання, інформаційно-освітня діяльність.

\section{ИСТОРИЯ СТАНОВЛЕНИЯ И РАЗВИТИЯ КООПЕРАТИВНОГО ДВИЖЕНИЯ В УКРАИНЕ В КОНЦЕ ХІХ - НАЧАЛЕ ХХ ВЕКА}

Аннотация. Определено, что для преодоления социально-экономических проблем сельских общин и изменения общественного строя в конце XIX - начале XX века в различных регионах Украины кооперативное движение получило широкое распространение и стало общегосударственным социально-экономическим явлением. Становление обслуживающей кооперации осуществлялось через создание сельскохозяйственных обществ и их объединений в кооперативные сообщества, союзы и центры развития. Доказано, что формирование кооперативного движения не происходило без вмешательства органов государственной власти, которые кроме принятия соответствующих нормативных документов постоянно пытались навязать общинам партийную идеологию через сотрудничество с кооперативной системой. Установлено, что в то же время кооперативные учреждения влияли на политическую жизнь страны путем финансирования партий и проведения агитационной работы среди населения.

Выяснено, что распространение кооперации происходило из-за массового осуществления кооперативами и их институциями культурно-просветительской, информационно-консультативной и образовательной работы. В частности, особое внимание уделялось созданию кооперативных кружков, школ, библиотек, проведению демонстрационных мероприятий и выставок, организации прокатных станций техники и оборудования.

Резюмирована целесообразность учета исторического опыта становления и развития кооперации как социально-экономического явления в государстве в современных условиях проведения реформы децентрализации полномочий власти и появления сельских объединенных территориальных общин. Отмечено, что для успешного развития сельских территорий Украины необходимо сосредоточить внимание на основных идеологически-организационных принципах возрождения и развития украинского кооперативного движения, воспитании национально сознательных членов общества, повышении культурно-образовательного и финансово-экономического уровня населения.

Ключевые слова: аграрная политика, кооперация, кооперативное движение, кооперативное объединение, информационно-образовательная деятельность. 
Problem statement. Cooperation, as a national social and economic phenomenon, is an important component of the development of agrarian relations and way of life in rural areas. The active phase of the formation and development of the cooperative movement in different regions of Ukraine fell to the end of the $19^{\text {th }}$ and early $20^{\text {th }}$ centuries. Such tendencies were preceded by several reasons. First of all, deteriorating social and economic situation in rural areas occurred in the process of its formation. The creation of different types of cooperatives also prompted the emergence of such problems as lack of funds, high cost and low quality of goods in shops, the need for intensification of agriculture, the need to improve the competitiveness of industries in the agricultural sector through the introduction of specialization [1, p. 15]. Subsequently, cooperatives began to take an active part in the social and economic life of the state thanks to the widespread spread. In addition to activating their activities in the agricultural sector, they encouraged the creation of various socially useful and religious institutions, provided funds for the needs of the army, the construction of hospitals, organized for members of the special mutual assistance funds, provided financial assistance to the victims of bad crop and the unemployed [2, p. 13, 15]. The history of the formation of cooperative relations and cooperative experience can be used in practice, since in the light of the best traditions of the past; the formation of cooperative relations in the retrospect can play an important role in the development of modern agrarian policy of the state [3, p. 5].
Analysis of recent publications on research issues. A lot of native scientists engaged in (researched) the issues of the formation and development of the cooperative movement in the late $19^{\text {th }}$ and early $20^{\text {th }}$ centuries in Ukraine [1-15]. However, the causes of the emergence and spread of cooperation as a national social and economic phenomenon, the integrated approach, taking into account the political component, defending national interests, and the organizational foundations for the functioning of cooperatives and their institutions are not followed in the scientific works.

The purpose of the article to clarify the role of cooperation as a national social and economic phenomenon and to define the main principles of the development of the cooperative movement in Ukraine taking into account the systemic approach.

\section{Presentation of the main material.} Ideological leaders who propagated their ideas with a view to overcoming social and economic problems and restructuring the social order played an important role in spreading the cooperation in rural areas. For example, penetration of the ideas of cooperation on the territory of Naddnipryanshchyna was held in the 1860's and 1870 's. There were different points of view on the importance of cooperative relations in society among the public. Some scientist defined cooperation as a form of social and economic development, which ultimately should lead to the construction of socialism, that is, a new social system. In contrast, others defined it as a way of protecting the material interests of the people. 
Thus, according to Sadovskyi's conviction, cooperation can develop without violating the fundamental principles of society and the state. The socialist essence of the cooperation was argued and supported by M. Drahomanov, M. Levitskyi, M. Ziber, S. Podolynskyi, M. Tuhan-Baranovskyi, V. Pekarskyi and others. They associated with cooperation the possibility of radical restructuring of the social system, the achievement of social harmony and justice. Representatives of the Populist Movement V. Dziubinskyi, P. Chervinskyi, F. Shcherbyna were engaged in developing a concept for the introduction of collective management. The values of collectivism and unity, mutual assistance, education, honesty and integrity in activities were promoted in the cooperative environment [4, p. 16, 23].

It was found out that the activity of the cooperative movement was at the beginning of the 90 's of the $19^{\text {th }}$ century in the South of Ukraine, and its significant development was observed after the revolutionary events of 1905-1907. By 1917 there were about 2,3 thousand cooperatives in the region. The spread of the cooperative movement dates back to the time of the Ukrainian national revival. The interests of cooperatives in the State Duma were represented by a small number of deputies, who set themselves the task of adopting a general cooperative law [2, p. 11].

It was established that the cooperative movement in Ukraine did not develop in itself at the national level. Formation, development and control over the distribution of it were entrusted to the state authorities. Some politicians used a cooperative system to impose party ideology on rural communities through mutually beneficial cooperation. Thus, the revolutionary events of 1905-1907 forced the authorities to implement a series of liberal measures for cooperative activities. A new phenomenon was the growing interest in cooperation by political parties, which evaluated its value in different ways. Some people completely supported it, others treated with a reservation [1, p. 18-19].

The development of cooperation was facilitated by the holding of local and provincial congresses. At the $2^{\text {nd }}$ All-Russian Cooperative Congress, which took place in Kyiv in the summer of 1913, an important step was taken in establishing Ukrainian cooperation as an independent economic force. At the turn of 1915-1916, the government was invited to consider the draft cooperative legislation, but the Council of Ministers rejected its adoption because of the reluctance to give up control over cooperation. The draft law was adopted in the State Duma after the February Revolution of 1917 with minor changes in the wording prepared by the cooperators. The struggle for democratic rights and freedoms for their own activities contributed to the activity of the cooperative movement, forcing the authorities to go to legislative acts and to treat it as an effective force in the public and political life of the country [5, p. 11]. During the period of the rise of the national and social struggle of the Ukrainian people during 1917-1920, the cooperative movement became more widespread, becoming a national social and economic phenomenon [6, p. 31]. 
In 1917, cooperatives acted as the only organized structure in Podillia that became the pillar of the economic policy of the Ukrainian Central Rada on the positions of Ukrainian statehood, in every way supporting the struggle for Ukraine's independence. The activities of institutions and organizations during the administration of the Directory were determined by the targeted policy of the governments of the UPR to strengthen cooperation as the main force capable of solving all economic problems of the country. In 1917-1919, the Bolsheviks persecuted and repressed members of the associations and their unions. In 1920, the cooperative organizations of the region were reorganized in accordance with the requirements of decrees. Ideology of reforms and methods of their implementation were aimed at the destruction of the cooperative movement [7, p. 15].

In 1920, the USSR initiated measures for the nationalization of cooperation in accordance with the Decrees of the People's Commissars of the RSFSR "On Consumer Communes" of March 20, 1919, and "On the Association of All Types of Cooperative Organizations" of January 27, 1920. As a result of the implementation of these decrees in action, the amateur cooperative system of Ukraine was destroyed. Together with the spread of cooperation among the general population, its rapid revival was facilitated by the new economic policy in the early 20's [8]. At that time, cooperatives contributed to the development of agriculture. Therefore, the party leadership sought through a cooperative system to attract peasants (farmers) to the idea of socia- lism. Some of them believed that no cooperation should be adapted to the NEP, but rather the NEP is needed to cooperate. This approach allowed promoting the ideas of socialism through mutually beneficial cooperation with the peasantry, which was the majority of the population of Ukraine, avoiding confrontation with it [9, p. 13].

At the beginning of the $20^{\text {th }}$ century, the anti-Ukrainian position of the Polish authorities, which perceived Ukrainian cooperation as a means of independence, was observed in the north-western Ukrainian lands. In accordance with the Orders of the President of Poland "On Industrial Law" dated 1926 and "On Construction Law" dated 1928, the representatives of the administration massively closed the Ukrainian cooperatives and hindered their registration because of inconsistency with the established sanitary norms. In the 1930s, Ukrainian cooperation in Poland was under state control. Thus, in accordance with the new legislation during 1934-1935, 435 Ukrainian cooperatives passed under the influence of Polish cooperative unions [10, p. 11-13].

The overwhelming majority of typical cooperatives in terms of the organizational and legal form of management were agricultural societies that began to function in Ukrainian provinces since the end of the $19^{\text {th }}$ century. The massive spread of the cooperative movement began in 1908 with the adoption of a model statute of an agricultural society, which provided for their simplified registration procedure. Thus, as of January 1, 1912, 34 cooperatives had already been operating in Ukraine, and their number reached more than 100 
units in 1915. Until 1918, there were the following types of societies functioned: procurement, marketing, processing and multifunctional in Ukraine [11, p. 135-137]. Thanks to the purchase and sale cooperation, there were carried out the purchase and sale of agricultural products, consumer goods, tools, agricultural machinery, seeds, and fertilizers [12, p. 11]. In 1922, since 2416 officially operating cooperative agricultural societies, almost all were registered as universal. In 1926, there were 4545 units [9, p. 16]. In the conditions of the growth of specialization and marketability of agriculture, in the rural communities are actively creating beetle, fruit and vegetable, milk, machine and tractor and other types of societies. The practice of cooperation in Ukraine proved that such organizational forms were more self-sufficient than collective farms [13, p. 11].

The lack of special knowledge of the governing bodies for managing cooperatives and lack of knowledge of the peasants in the principles of cooperation often led to the instability of their work. The low activity of the peasants and the insufficient number of quorums at meetings often paralyzed the work of the cooperative. Separately, there were problems in fulfilling the obligations assumed by the members. Subsequently, the problems began to be solved by introducing various methods of organizational, and in some cases, administrative influence through the imposition of penalties, bringing the perpetrators to justice in court and excluding them from the cooperative [4, p. 28].

It should be noted that the organization of the activity of agricultural cooperatives and the attraction of more members to them in the overwhelming majority was due to the work of cooperative organizations with the rural population through the introduction of various methods and forms of cooperation. Among them: carrying out cultural and educational activities, training of skilled workers, providing information and consulting services, distributing special educational literature, setting up of cooperative libraries, organizing exhibitions, conducting demonstration shows, and the creation of rolling stations of agricultural machinery and equipment.

It was established that for the educational activity, close cooperation was established between cooperatives with rural houses and huts-reading rooms. There were created cooperative corners, circles, schools and libraries, where lectures, holidays, parties and performances were usually held. The main reason for the establishment of cooperative circles and schools was that there were few qualified specialists in the village to teach peasants (farmers) the basics of agrarian production. At the same time, the government organized schools to train young people for agriculture only, depriving the rest of the rural population of education. Qualified specialists were invited, namely: agronomists, veterinarians and gardeners for lectures on short-term courses in cooperative schools. [14, p. 18-19]. Thanks to the training activities of ordinary peasants, it was hoped to be involved in the use of advanced achievements in agricultural science and technology, which in turn should have affected the increase in the profitability of their farms. The best achievements in the field of plant growing and 
livestock were introduced into practice through the provision of information and advisory services.

The organization of agricultural exhibitions demonstration of new methods of management greatly contributed to the popularization of the idea of cooperative movement and increases the productivity of peasant farms. In particular, demonstration fields and sites were created to demonstrate the benefits of using new technologies for land cultivation in the South of Ukraine. Cooperatives organized rolling mills, where it was possible to use the technique and new advanced equipment for a moderate fee [2, p. 13].

During the 80 's of the $19^{\text {th }}$ and early $20^{\text {th }}$ centuries, institutions such as cooperative unions, unions, specialized systems and other institutions played a significant role in shaping the cooperative movement in recognition of the role and importance of cooperation with the rural population and its scale in almost all regions of the country. Thus, regional cooperative associations (unions) were intermediaries, coordinators and controllers of the activities of local unions. They helped to financially and economically strengthen the existing and the emergence of new alliances, especially savings and credit treasuries, sought state assistance in expanding the lending of peasants' offices and societies with cheap loans, adjusted supply of peasants through unions with relatively cheap goods, organized sales of agricultural products, and supported various kinds of industrial unions. In addition, the unions engaged in the training of cooperatives in the village, promoted the knowledge of members of the unions, as well as na- tional and civic consciousness of the peasants, and their unification in protecting their rights [15, p. 9].

The social processes that took place during the years of the Ukrainian Revolution significantly improved the conditions for the activities of cooperative organizations. The approval of the "Regulations on Cooperative Societies and their Unions" contributed to the creation of new cooperatives and cooperative unions in Ukraine. All-Ukrainian cooperative congresses, which took place in April and September 1917, called for the creation of their own national Ukrainian cooperative centres. All-Ukrainian cooperative unions began their work. Cooperative institutions financed a variety of Ukrainian and all-Russian socialist parties, campaigned (carried out propaganda work), and influenced the country's political life. In 1918, a Program was adopted at the All-Ukrainian Cooperative Congress. It provided for the creation of new national cooperative centres. Due to the implementation of the measures, the cooperative network comprised 14 to 18 thousand organizations with almost 7 million members, and the number of their unions exceeded 200 units. In April 1920, the All-Ukrainian Cooperative Union (Centrospilka), which united in its composition all the national cooperation centres and thus completed the administrative structure of the cooperative system of the country, began work [8].

Right-bank Ukraine agricultural cooperation tried to unite disparate societies in order to coordinate their work as a result, the Kiev Central Agricultural Society was founded. Al- 
though its activities began to unfold in 1916, and it was not the only centre for agricultural cooperation for Ukraine. It did a unifying, organizational and educational function [5, p. 12]. There were formed such powerful specialized systems as Dobrobut, Cooptakh, Plodospilka, Nisinniesoiuz, Ukrsiltsukor and Buriakospilka in the general structure of agricultural cooperatives of Ukraine. Due to uniting, agricultural cooperation has become a powerful and highly effective instrument capable of achieving rapid modernization of the agrarian sector of Ukraine's economy [9, p. 17]. Subsequently, FARMER, All-Ukrainian Union of Agricultural Cooperatives began to operate on the Left-bank Ukraine. However, due to the proliferation of mass collectivization in Ukraine in 1929, its activities were completely stopped.

In the 1926-1930, the bulk and selling cooperation had a three-stage structure on the territory of the Volyn Voivodship. Cooperatives of the $1^{\text {st }}$ degree united in the county or district unions, thus creating cooperatives of the $2^{\text {nd }}$ degree. The latter united in Centrosoiuz, National Centre of Common Purchasing and Sales Cooperatives as cooperatives of the $3^{\text {rd }}$ degree. At the end of 1934, there were 282 cooperatives of the 1st degree and 4 district associations of cooperatives in the Volyn Voivodship that were subordinated to Centrosoiuz [12, p. 11].

Conclusions and prospects for further researches. Thus, at the end of the $19^{\text {th }}$ and early $20^{\text {th }}$ centuries, the cooperative movement has become widespread becoming a national social and economic phenomenon. It is confirmed by the existence of a significant number of cooperative organizations, large cooperative unions and development cooperation centres. The formation of service cooperatives was carried out mainly through the creation of agricultural societies. However, it should be noted that with the approval of the totalitarian system and the imposition of collectivization by the rural communities, the cooperative movement began to gradually lose its position on the territory of Ukraine. Nevertheless, the analysis of the formation and spread of the cooperative movement in rural communities in this period allows us to draw the following conclusions:

Firstly, it had an important place in the social and political, social and economic life of the state, forming new values of life from the peasants, developing their initiative, amateur action, personal responsibility to themselves and the community for the results of their actions, and the ability to solve complex issues through interaction with other members;

Secondly, cooperatives and their associations were guided by common cooperative principles in the process of their development, namely: meeting the needs of the participants and improving their living conditions, voluntary entry and exit from the association, participation in the formation of the financial base of the cooperative at the expense of share contributions, and the implementation of management on a democratic basis;

Thirdly, the desire of the authorities to control cooperative formations led to the legislative regulation of their activities through various decrees, laws, decrees, rules and other legal documents; 
Fourthly, the cultural-educational, informational and consultative and educational work of cooperative entities was essential in addition to providing services to the population in various spheres of economic activity, which consisted in the wide propagation of the leading ideas, the education of conscious cooperatives, and the introduction of new knowledge in agriculture.

It should be noted that during the period of mass spread of cooperation in Ukraine in the late $19^{\text {th }}$ and early $20^{\text {th }}$ centuries, the political component in the formation of a cooperative movement is clearly followed, which consists not only in the adoption of relevant normative documents by the state authorities, but also in attempts to impose a party ideology through the cooperative system. An important place in the retrospective analysis was the experience of organizing the activities of both the cooperatives themselves and their institutional environment.

Consequently, it is expedient to take into account the historical experience of the formation and development of cooperation as a social and economic phenomenon in the state in the current conditions of the reform of decentralization of power and the emergence of united territorial communities, especially in rural areas, in further research. In particular, the main principles of dissemination of the ideological and organizational principles of revival and further development of the Ukrainian cooperative movement, upbringing of nationally conscious members of society, and raising the cultural, educational and economic levels of the rural population, as a prerequisite for the successful development of Ukrainian rural areas deserve attention.

\section{REFERENCES}

1. Mahas-Demydas Yu. I. (2008). Kooperatyvnyi rukh Pravoberezhnoi Ukrainy u 1860-ti - 1914 roky [Cooperative Movement of Right-Bank Ukraine in the 1860's - 1914]. Extended abstract of candidate's thesis. Cherkasy [in Ukrainian].

2. Piatnytskova I. V. (2010). Rol kooperatsii $v$ zhytti naselennia Pivdnia Ukrainy naprykintsi XIX - na pochatku XX st. [The role of cooperation in the life of the South of Ukraine in the late $19^{\text {th }}$ - early $20^{\text {th }}$ centuries]. Extended abstract of candidate's thesis. Donetsk [in Ukrainian].

3. Panteleimonenko A. O. (2008). Ahrarna kooperatsiia Ukrainy: teoriia i praktyka [Agrarian Cooperation of Ukraine: Theory and Practice]. Poltava: RVV PUSKU [in Ukrainian].

4. Farenii I. A. (2009). Kooperatyvnyi rukh u Naddniprianskyi Ukraini v druhii polovyni XIX - na pochatku $\mathrm{XX}$ stolittia [Cooperative movement in the Dnieper Ukraine in the second half of the $19^{\text {th }}-$ early $20^{\text {th }}$ century]. Extended abstract of doctor's thesis. Kyiv [in Ukrainian].

5. Dvoininova O. V. (2004). Kooperatsiia v silskomu hospodarstvi Pravoberezhnoi Ukrainy (1906 - liutyi 1917 rr.) [Cooperation in the agriculture of the Right-Bank Ukraine (1906 - February 1917)]. Extended abstract of candidate's thesis. Ivano-Frankivsk [in Ukrainian].

6. Prylipko S. M. (n.d.). Istoriia stanovlennia obsluhovuiuchoi kooperatsii u silskykh terytorialnykh hromadakh Ukrainy [History of Establishment of Service Cooperation in Rural Territorial Communities of Ukraine]. Proholoshennia nezalezhnosti UNR: dosvid 
dlia suchasnoho derzhavotvorennia Proclamation of Independence of the UPR: experience for modern state-building: Proceedings of AllUkrainian extramural scientific-practical conference dedicated to the $100^{\text {th }}$ anniversary of the 4th Universal of the Ukrainian Central Rada. (p. 31-33). Kyiv: NADU [in Ukrainian].

7. Yatsenko O. V. (2011). Kooperatyvnyi rukh na Podilli v roky Ukrainskoi revoliutsii (1917-1921 rr.) [Cooperative movement in Podillia during the years of the Ukrainian Revolution]. Extended abstract of candidate's thesis. Chernihiv [in Ukrainian].

8. Farenii I. A. (2000). Ukrainskyi kooperatyvnyi rukh u period 1917-1920 rokiv (istorychnyi aspekt) [Ukrainian cooperative movement in the period 1917-1920]. Extended abstract of candidate's thesis. Cherkasy [in Ukrainian].

9. Bychenko S. M. (2010). Vnesok silskohospodarskoi kooperatsii u zmitsnennia dobrobutu selianstva Ukrainy (1921-1929 rr.) [The contribution of agricultural cooperation to the change of the welfare of the peasantry of Ukraine (1921-1929)]. Extended abstract of candidate's thesis. Cherkasy [in Ukrainian].

10. Drahomyretska L. R. (2004). Ukrainska kooperatsiia u hromadsko-politychnomu zhytti Zakhidnoi Ukrainy (1920-1939 rr.) [Ukrainian cooperation in the public-political life of Western Ukraine (1920-1939)]. Extended abstract of candidate's thesis. Ivano-Frankivsk [in Ukrainian].

11. Panteleimonenko A. O. (2006). Stanovlennia kooperatsii v ukrainskomu seli: istoryko-ekonomichni aspekty [Formation of cooperation in the Ukrainian village: historical and economic aspects]. Poltava: RVTs PUSKU [in Ukrainian].
12. Visyna T. M. (2002). Ukrainskyi kooperatyvnyi rukh u Volynskomu voievodstvi v 20-30-kh rokakh XX st. [Ukrainian Cooperative Movement in the Volyn Voivodeship in the 20-30's of the $20^{\text {th }}$ century]. Extended abstract of candidate's thesis. Lviv [in Ukrainian].

13. Filipov K. V. (1999). Silskohospodarska kooperatsiia Ukrainy v 20-i roky $\mathrm{XX}$ stolittia [Agricultural cooperatives of Ukraine in the 20's of the $20^{\text {th }}$ century]. Extended abstract of candidate's thesis. Kharkiv [in Ukrainian].

14. Dulherova O. M. (2006). Kulturnoosvitnia diialnist silskohospodarskoi kooperatsii Ukrainy u dobu NEPu [Cultural and educational activity of agricultural cooperation of Ukraine in the days of the NEP]. Extended abstract of candidate's thesis. Cherkasy [in Ukrainian].

15. Botushanskyi O. V. (2001). Silska kooperatsiia na Bukovyni (80-ti roky XIX - pochatok XX st.) [Rural Cooperation in Bukovina (80's of the $19^{\text {th }}-$ early $20^{\text {th }}$ centuries)]. Extended abstract of candidate's thesis. Chernivtsi [in Ukrainian].

\section{СПИСОК ВИКОРИСТАНИХ ДЖЕРЕЛ}

1. Магась-Демидас Ю. І. Кооперативний рух Правобережної України у 1860-ті - 1914 роки : автореф. дис. ... канд. іст. наук : 07.00.01 / Ю. І. Магась-Демидас. - Черкаси, 2008. $28 \mathrm{c}$.

2. Пятницькова I. В. Роль кооперації в житті населення Півдня України наприкінці XIX - на початку XX ст. : автореф. дис. ... канд. іст. наук : 07.00.01 / І. В. Пятницькова. - Донецьк, 2010. -20 с.

3. Пантелеймоненко А. О. Аграрна кооперація України: теорія і практика: монографія / А. О. Пантелеймо- 
ненко. - Полтава : РВВ ПУСКУ, 2008. - 347 c.

4. Фареній I. A. Кооперативний рух у Наддніпрянський Україні в другій половині XIX - на початку XX століття : автореф. дис. ... д-ра іст. наук : 07.00.01 / I. А. Фареній. Київ, 2009. - 38 с.

5. Двойнінова О. B. Кооперація в сільському господарстві Правобережної України (1906 - лютий 1917 рр.) : автореф. дис. ... канд. іст. наук : 07.00.01 / О. В. Двойнінова. Івано-Франківськ, 2004. - 20 с.

6. Приліпко С. М. Історія становлення обслуговуючої кооперації у сільських територіальних громадах України / С. М. Приліпко // Проголошення незалежності УНР: досвід для сучасного державотворення : матеріали Всеукр. заочної наук.практ. конф., присвяченої 100-річчю IV Універсалу Української Центральної Ради (29.03.2018 р.). - К. : НАДУ. - С. 31-33.

7. Яценко О. В. Кооперативний рух на Поділлі в роки Української революції (1917-1921 рр.) : автореф. дис. ... канд. іст. наук : 07.00.01 / О. В. Яценко. - Чернігів, 2011. $20 \mathrm{c}$.

8. Фареній I. А. Український кооперативний рух у період 1917-1920 років (історичний аспект): автореф. дис. ... канд. іст. наук : 07.00.01 / I. А. Фареній. - Черкаси, 2000. $15 \mathrm{c}$.

9. Биченко С. М. Внесок сільськогосподарської кооперації у зміцнення до- бробуту селянства України (19211929 рр.) : автореф. дис. ... канд. іст. наук : 07.00.01 / С. М. Биченко. Черкаси, 2010. - 20 с.

10. Драгомирецька Л. Р. Українська кооперація у громадсько-політичному житті Західної України (19201939 рр.) : автореф. дис. ... канд. іст. наук : 07.00 .01 / Л. Р. Драгомирецька. - Івано-Франківськ, 2004. $24 \mathrm{c}$.

11. Пантелеймоненко А. О. Становлення кооперації в українському селі: історико-економічні аспекти : монографія / А. О. Пантелеймоненко. Полтава : РВЦ ПУСКУ, 2006. $227 \mathrm{c}$.

12. Вісина T. М. Український кооперативний рух у Волинському воєводстві в 20-30-х роках XX ст. : автореф. дис. ... канд. іст. наук : 07.00.01/ Т. М. Вісина. - Львів, 2002. - 20 с.

13. Філіпов К. В. Сільськогосподарська кооперація України в 20-ті роки XX століття : автореф. дис. ... канд. іст. наук : 07.00 .01 / К. В. Філіпов. Харків, 1999. - 20 с.

14. Дулгерова О. М. Культурно-освітня діяльність сільськогосподарської кооперації України у добу НЕПу : автореф. дис. ... канд. іст. наук : 07.00.01 / О. М. Дулгерова. - Черкаси, 2006. - 24 с.

15. Ботушанський О. В. Сільська кооперація на Буковині (80-ті роки XIX - початок XX ст.) : автореф. дис. ... канд. іст. наук : $07.00 .01 /$ О. В. Ботушанський. - Чернівці, 2001. - 20 c. 